\title{
ICE-D Out: A Constitutional Relatedness Analysis of the Bonus Points Awarded to Jurisdictions Cooperating With Federal Immigration Goals
}

\author{
Ryan Kelly*
}

\section{INTRODUCTION}

In an almost circadian rhythm, the American public has become accustomed to waking up each morning with breaking news of the Trump administration's changes to the immigration system in the United States. ${ }^{1}$ Whether Lilliputian changes or Himalayan overhauls, each policy enacted by the administration fundamentally changes what due process means in immigration courts. ${ }^{2}$ In response to President Trump's efforts to increase deportations of migrants ${ }^{3}$ in this country, many localities have instituted

* Ryan P. Kelly, J.D. 2020, University of Kansas School of Law; B.B.A. International Business and Marketing (2017), Washburn University. I want to thank Lindsey Collins at the KU Medical-Legal Partnership, Professor Richard Levy, attorney Clare Murphy Shaw and Katalina Barron with the McCrummen Immigration Law Group, my partner in life Josué Rivera, my family of Irish and Chinese immigrants (Patrick Kelly, Lisa Kelly, Bailey Kelly, Ella Ryley Min Kelly, and extended), my Vietnamese family (Nguyễn David, Lê Thị Hông, Nguyễn Thuỳ Trang, Nguyễn Thanh Kim, Nguyễn Kevinh, and extended), McKenzie Tignor, Livier Romo, Montana Browning, the ladies of the SBG (Trang Nguyen, Hope Werner, Marissa Meis, and Katie Price), and my law school friends (Hannah Bedford, Carly Grit, and Emily Matta) for all their support and influence in this Comment. "Immigration policy should be generous; it should be fair; it should be flexible. With such a policy we can turn to the world, and to our own past, with clean hands and a clear conscience." JOHN F. KENNEDY, A NATION OF IMMIGRANTS 82 (1986).

1. See Lorella Praeli, The Trump Administration's Multi-Pronged Assault on Immigrants' Rights, ACLU (Mar. 19, 2018, 4:30 PM), https://www.aclu.org/blog/immigrants-rights/trumpadministrations-multi-pronged-assault-immigrants-rights [https://perma.cc/6ZA6-QAWM]; see also Joshua Barajas, How Trump Has Already Changed Immigration Policy, PBS News HouR (Feb. 6, 2019, 12:37 AM), https://www.pbs.org/newshour/politics/how-trump-has-already-changedimmigration-policy [https://perma.cc/PQY2-R32F].

2. See Jens Manuel Krogstad \& Ana Gonzalez-Barrera, Key Facts About U.S. Immigration Policies and Proposed Changes, PEw RsCH. CTR. (May 17, 2019), https://www.pewresearch.org/facttank/2019/05/17/key-facts-about-u-s-immigration-policies-and-proposed-changes [https://perma.cc/243E-N8N7].

3. The word "migrant(s)" is specifically used in this paper instead of any other descriptive term (such as "immigrants") to refer to individuals present in the United States without authorization. "Migrant(s)" is a more appropriate term to recognize the struggle that many go through when entering 
policies to limit cooperation between their officials and Immigration and Customs Enforcement (ICE). ${ }^{4}$ The Trump administration, as it promised in its 2016 campaign, ${ }^{5}$ shifted its focus to undercutting migrant-inclusive initiatives by attempting to condition states' abilities to secure federal funding on whether they act in accord with federal immigration goals. ${ }^{6}$ Courts around the nation have scrutinized these attempts, finding that these efforts violated the Constitution. ${ }^{7}$

This is the backdrop for the back-and-forth between Trump implementing immigration-related spending conditions and the courts subsequently invalidating them. Yet, fortunately for the Trump administration, and unfortunately for its dissenters, a panel in the Ninth Circuit recently came to a differing conclusion. ${ }^{8}$ When looking at how jurisdictions that cooperate with the Trump administration on immigration were given extra points in their grant applications, the panel found, 2-1, that the preferential policy was constitutional. ${ }^{9}$ Although this grant program is a seemingly small piece of the overall immigration patchwork, it is a powerful example of the model the Department of Justice (DOJ) employs for its immigration goals. ${ }^{10}$ These

the United States, especially in Trump's contemporary political environment, because it connotes a lack of permanency of residency, which reflects the efforts being made by Trump and his administration to expel migrants from this country. Migrants are consistently having to move around in order to hide, seek protection, avoid family separation, and stay safe.

4. Jonathan Allen, U.S. Mayors Decry Trump Sanctuary City Threat, 'Prepared to Welcome' Migrants, REUTERS (Apr. 12, 2019, 2:17 PM), https://www.reuters.com/article/us-usa-immigrationsanctuary-mayors/u-s-mayors-dismiss-trump-sanctuary-city-threat-prepared-to-welcome-migrantsidUSKCN1RO2E3 [https://perma.cc/C63D-FYW6].

5. Pamela Engel, Trump's First 100 Days Were Unlike Any We've Ever Seen - Here Are All the Promises He's Kept and Broken, Bus. INSIDER (Apr. 29, 2017, 7:53 AM), https://www.businessinsider.com/trump-first-100-days-promises-2017-4 [https://perma.cc/7BEYMT6U] (noting Trump's campaign promise to end federal funding to "sanctuary cities" in his first 100 days in office).

6. Suzanne Monyak, 9th Circ. Says DOJ Can Tie Police Funds to Immigration, LAw360 (July 15, 2019, 10:00 PM), https://www.law360.com/articles/1178029/9th-circ-says-doj-can-tie-policefunds-to-immigration [https://perma.cc/UK46-YU88].

7. See City of Philadelphia v. Sessions, 309 F. Supp. 3d 289, 321 (E.D. Pa. 2018), aff'd in part, vacated in part sub nom. City of Philadelphia v. Att'y Gen., 916 F.3d 276, 284-91 (3d Cir. 2019); City of Chicago v. Sessions, 888 F.3d 272, 283-87 (7th Cir. 2018), vacated in part on other grounds, No. 17-2991, 2018 WL 4268817 at *1 (7th Cir. June 4, 2018); New York v. Dep't of Just., 343 F. Supp. 3d 213, 227-31 (S.D.N.Y. 2018), overruled by New York v. Dep't of Just., 951 F.3d 84, 124 (2d Cir. 2020); City \& Cnty. of San Francisco v. Sessions, 349 F. Supp. 3d 924, 945-48, 954-55 (N.D. Cal. 2018), aff'd in part, vacated in part sub nom. City \& Cnty. of San Francisco v. Barr, 965 F.3d 753, 766 (9th Cir. 2020); City of Chicago v. Sessions, 321 F. Supp. 3d 855, 874-76 (N.D. Ill. 2018), aff'd sub nom. City of Chicago v. Barr, 961 F.3d 882, 931-32 (7th Cir. 2020).

8. See City of Los Angeles v. Barr, 929 F.3d 1163, 1182-83 (9th Cir. 2019).

9. Id.

10. See Miriam Valverde, Despite Efforts, Donald Trump Fails to Cut Funding from Sanctuary Cities, POLITIFACT (Jan. 14, 2019), https://www.politifact.com/truth-ometer/promises/trumpometer/promise/1400/cancel-all-funding-sanctuary-cities/ [https://perma.cc/34PY-934B]. 
policies and programs are part of a broader approach to meet Trump's goals of increasing deportations and reducing both "legal and illegal immigration" in the United States. ${ }^{11}$ Yet, a rarely challenged requirement of the Spending Clause in the Constitution could be a new obstacle in the administration's way. A requirement of the Spending Clause in the Constitution, the relatedness requirement, ${ }^{12}$ has only been cursorily analyzed by courts since it was established. ${ }^{13}$ If the courts analyzed this prong with more force, they would likely find the conditions on the Community Oriented Policing Services (COPS) program in the City of Los Angeles v. Barr case violate the relatedness prong of the Spending Clause. ${ }^{14}$

First, this Comment will analyze immigration law in general, focusing on the Immigration and Nationality Act and the regulations that govern laws relevant to this Comment's analysis. Then, the Comment discusses sanctuary cities and sets the stage for an analysis of the Trump administration's spending conditions instituted against cities to foster support for the administration's immigration goals. With this backdrop, the Comment then discusses the case in question, City of Los Angeles v. Barr, ending with the dissent's transition to the relatedness analysis. Finally, this Comment argues for an increased relatedness standard, pursuing three different tests that could strengthen this prong of the Spending Clause. Under any strengthened test, the conditions on the City of Los Angeles case would likely be held constitutionally invalid.

\section{BACKGROUND}

\section{A. Immigration Law Overview}

The Immigration and Nationality Act (INA), passed in 1952, generally governs immigration law in this country. ${ }^{15}$ The Act sets out the basic body of immigration law, including paths to citizenship, such as asylum and visas. ${ }^{16}$ Included in the INA are regulations governing the DOJ and the rules for

11. Ted Hesson, Trump Administration Expands Scope of Rapid Deportations, Politico (July 22, 2019, 10:23 AM), https://www.politico.com/story/2019/07/22/trump-administration-immigrantdeportations-dhs-1607459 [https://perma.cc/VH47-9M6Q].

12. U.S. ConsT. art. I, § 8, cl. 1; see also South Dakota v. Dole, 483 U.S. 203, 207-08 (1987) (noting "conditions on federal grants might be illegitimate if they are unrelated to the federal interest").

13. See Andrew Nolan, Kevin M. Lewis, Jay B. Sykes, Wilson C. Freeman, \& Kevin J. Hickey, CONG. RSCH. SERV., R45323, Federalism-BASEd Limitations on CONGRESSiONAL POWER: AN OVERVIEW 31 (2018) (noting "most lower courts have given the 'relatedness' requirement 'only cursory attention,' and 'have had little difficulty upholding a wide range of funding conditions without a clearly explained relationship to the underlying legislation."').

14. See infra Section III.

15. Immigration \& Nationality Act, 8 U.S.C. $\S \S 1101-1537$.

16. See generally id. 
immigration agencies. ${ }^{17}$ Originally, beginning in 1933, the agency that governed immigration law was the Immigration and Naturalization Service. ${ }^{18}$ It was initially contained in the Department of Labor, but the agency was moved under the Department of Justice in 1940. ${ }^{19}$ The INS lasted until 2003 when the government transformed the agency into "three different agencies under the Department of Homeland Security: The U.S. Citizenship and Immigration Services (USCIS), the U.S. Immigration and Customs Enforcement (ICE), and the U.S. Customs and Border Protection (CBP)." 20 The September 11, 2001 terrorist attacks primarily motivated this shift. ${ }^{21}$ These three branches of the Department of Homeland Security (DHS) have different roles. USCIS is primarily in charge of "applications and petitions for immigration and naturalization benefits." 22 CBP and ICE are fairly similar. CBP enforces immigration laws "at and between the ports of entry", while ICE enforces immigration laws within the U.S. interior. ${ }^{23}$ ICE also controls both "detention and removal operations." 24 Under these different branches, there are many different pathways that individuals can take to gain legal status in the United States, depending on their specific factual background or the conditions of their home country. ${ }^{25}$

The Trump administration has expanded the role of ICE. ${ }^{26}$ The Trump administration widened the agency directive to target "undocumented immigrants regardless of whether or not they had committed a serious crime." 27 This led to a forty-two percent increase in arrests during Trump's first nine months in office. ${ }^{28} \mathrm{ICE}$, in its efforts to deport more undocumented individuals in this country, has pursued agreements with localities known as

17. Id. at $\S \S 1101-1105 \mathrm{a}$.

18. USCIS and INS History, IMMIGR. RD., (last visited Oct. 3, 2020), https://immigrationroad.com/resource/uscis-ins-history.php [https://perma.cc/CBS6-D5KD].

19. Id.

20. Id.

21. Sabrina Siddiqui, 'We Protect Ice': Trump Supporters Rally Behind Immigration Slogan, THE GuARDIAN, (July 8, 2018, 2:00 PM), https://www.theguardian.com/us-news/2018/jul/08/iceimmigration-customs-enforcement-trump-democrats [https://perma.cc/G7HK-4RT8].

22. Immigration Enforcement Actions, DeP'T OF HoMELAND SEC. (Apr. 5, 2016), https://www.dhs.gov/immigration-statistics/enforcement-actions [https://perma.cc/7QJD-28AD].

23. $I d$.

24. Id.

25. The immigration system for individuals seeking lawful status is outside of the scope of this paper. However, the following source provides a primer on immigration law in the United States. See generally William A. KANDEl, CONG. RSCH. SERV., R45020, A PRIMER ON U.S. IMMigRATION POLICY (2018) (describing the dual sides of the immigration system, focusing on one side of the affirmative visa processes and the other side of the defensive processes against removal, among other facets of the process for individuals).

26. Siddiqui, supra note 21.

27. $I d$.

28. Id. 
$\S 287(\mathrm{~g})$ agreements. ${ }^{29}$ These agreements are based on Section $287(\mathrm{~g})$ of the INA and "became law as part of the Illegal Immigration Reform and Immigrant Responsibility Act of 1996 (IIRAIRA)." ${ }^{30}$ These $\S 287(\mathrm{~g})$ agreements delegate immigration authority to localities so that their police officers may act like ICE agents. ${ }^{31}$ As of this Comment's writing, there are fifty-two jurisdictions that have "signed $287(\mathrm{~g})$ agreements during the Trump administration." 32 The goal of the agreement is to focus on "collaboration" between ICE and localities, but the American Immigration Council notes that the program "has been costly for localities, has not focused on serious criminals, and has harmed the relationship between police and local communities." ${ }^{33}$

Due to the tensions surrounding the Trump administration's immigration policy and $\S 287(\mathrm{~g})$ agreements, some jurisdictions have pursued sanctuary laws as a response. These sanctuary ordinances directly conflict with $\S 287(\mathrm{~g})$ agreements. The point of the agreement is to expand the Trump deportation regime, while sanctuary movements seek disentanglement from said regime. ${ }^{34}$ The politics of the area seem to have an effect on whether the locality welcomes a $\S 287(\mathrm{~g})$ agreement or pursues a sanctuary noncooperation policy. Yet, sanctuary cities require a more in-depth understanding due to their relevance in this conflict.

\section{B. Sanctuary Cities}

Sanctuary cities are at the heart of this conflict. The origin of a sanctuary city is nothing new, in fact, it is an "ancient concept." 35 The purpose of a sanctuary city is to be a place of refuge for migrants in the face of a government seeking to displace them from the confines of its national borders. ${ }^{36}$ In many ways, these cities have begun to encompass the migrant's

29. See 8 U.S.C. § 1357(g); see also Laura Muñoz Lopez, How 287(g) Agreements Harm Public Safety, CTR. FOR AM. PROGRESS (May 8, 2018, 9:01 AM), https://www.americanprogress.org/issues/immigration/news/2018/05/08/450439/287g-agreementsharm-public-safety/ [https://perma.cc/FQT4-ZMY8].

30. The 287 $(\mathrm{g})$ Program: An Overview, AM. IMMIGR. CouncIL 1 (July 2, 2020), https://www.americanimmigrationcouncil.org/research/287g-program-immigration [https://perma.cc/28LX-QDNF].

31. See National Map of 287(g) Agreements, ImmigRANT Legal Res. CTR. (Nov. 27, 2019), https://www.ilrc.org/national-map-287g-agreements [https://perma.cc/CYN4-ZER3].

32. $I d$.

33. The 287(g) Program: An Overview, supra note 30.

34. See Sanctuary Policies: An Overview, AM. IMMIGR. CounCIL (Feb. 23, 2017), https://www.americanimmigrationcouncil.org/research/sanctuary-policies-overview [https://perma.cc/8Z7L-FEZN].

35. Ananya Roy, The City in the Age of Trumpism: From Sanctuary to Abolition, 37 ENV'T \& PLANNING D: SOC'Y \& SPACE 761, Abstract (2019).

36. Id. 
"struggle in the United States, connoting resistance to white nationalism and the defiance of federal immigration policy." 37 However, sanctuary cities are not without their critics, from both sides of the political aisle. ${ }^{38}$ Despite this opposition, cities across the United States have attempted to make their localities safer for those not authorized to be in this country. ${ }^{39}$ Apart from the overarching philosophical goals of sanctuary cities, the practical goals and their history are also important to understanding their fight with the Trump administration because they highlight the tension on both sides of the immigration debate. It is important to note that 'sanctuary city' is not a legal term. ${ }^{40}$ It is used broadly (and arguably vaguely) to refer to cities' noncooperation policies with the federal government, encompassing all the various methods and degrees of noncooperation. ${ }^{41}$

For over 20 years, the federal government has employed local police forces to help "find, arrest, and deport immigrants." 42 At the same time, progressive lawmakers have attempted to "reassert local autonomy" in an effort to detangle federal immigration enforcement from local law enforcement. ${ }^{43}$ These attempts have toed the line between affirmatively obstructing the federal government and simply deciding to abstain from helping it. ${ }^{44}$ When the localities cooperate, the federal government is much more effective at deporting migrants, explaining the frustration it has when localities are disobliging. ${ }^{45}$ The Trump administration has been primarily concerned with local jails failing to release migrants in their control to federal immigration enforcement. ${ }^{46}$ Legally speaking, localities "aren't required to help the federal government" ${ }^{\text {" } 77}$ with immigration enforcement, meaning there

\footnotetext{
37. Id.

38. See id. (describing a liberal critique of sanctuary cities as statist violence); Seung Min Kim, Lawmakers Eye Crackdowns on 'Sanctuary Cities', PoLITICO (July 21, 2015, 7:02 PM), https://www.politico.com/story/2015/07/congress-sanctuary-citiesimmigration-fight-120438 [https://perma.cc/BM29-4JYL] (discussing conservative attempts to bar sanctuary cities).

39. Allen, supra note 4.

40. Dara Lind, Sanctuary Cities, Explained, Vox (Mar. 8, 2018, 12:00 PM), https://www.vox.com/policy-and-politics/2018/3/8/17091984/sanctuarycities-city-state-illegal-immigration-sessions [https://perma.cc/79FE-LK6V].

41. Id.

42. $I d$.

43. Id.

44. Id.

45. Id. ("Each year, from 2011 to 2014 - the peak of local-federal immigration cooperation a single local-federal program, Secure Communities (which checked immigrants booked into local jails against federal databases), resulted in the deportation of more than 70,000 immigrants. Secure Communities got more immigrants deported during those years than the entire federal government had in 1996.").

46. Id.

47. Id. (emphasis in original).
} 
is no "legal obligation." 48 At the same time, localities cannot prevent the federal government from obtaining information related to an individual's immigration status according to the vague distinction in Section 1373 of Chapter 8 of the United States Code. ${ }^{49}$ This part of the United States Code prohibits localities from interfering with the DHS agencies obtaining immigration information about "any individual." ${ }^{" 50}$ Localities, however, have argued that they are able to refrain from giving the federal government information regarding jail locations and release dates and still comply with the law, because such information is not directly related to immigration status. ${ }^{51}$

Oregon exemplifies an ideal sanctuary community and has been used a model for other states. ${ }^{52}$ Oregon's sanctuary law dates back more than thirty years,$^{53}$ and mandates that "state and local law enforcement resources can't be used to find or detain people whose only violation of the law is being in the country illegally." 54 Although some rebut characterizing Oregon's model as a "sanctuary," 55 the resulting disagreements are the same-the federal government desires information about undocumented migrants that the states or localities refuse to provide. Although Oregon's law dates back to before the Trump administration, ${ }^{56}$ the situation that brought about this law mirrors the contemporary fight, including similar racially-motivated supporters of

48. National Map of Local Entanglement with ICE, IMMIGR. LEGAL ReS. CTR. (Nov. 13, 2019), https://www.ilrc.org/local-enforcement-map [https://perma.cc/XC6F-A9RK].

49. Lind, supra note 40; see also 8 U.S.C. $\$ 1373$, invalidated by City of Chicago v. Barr, 405 F. Supp. 3d 748, 762 (N.D. Ill. 2019).

50. 8 U.S.C. $\$ 1373$. This section formerly applied to the Immigration and Naturalization Service, but the law transferred its "functions" to the new agency. See USCIS and INS History, supra note 18 .

51. Lind, supra note 40; see also Steinle v. City \& Cnty. of San Francisco, 230 F. Supp. 3d 994, 1014-16 (N.D. Cal. 2017).

$\begin{array}{cccccrr}52 . & \text { Conrad Wilson, } & \text { Oregon Was First Sanctuary } & \text { Community to } & \text { Respond to } \\ \text { ICE } & \text { Subpoenas, } & \text { E. } & \text { OREGONIAN } & \text { (Feb. } & 27, & 2020 \text { ), }\end{array}$ https://www.eastoregonian.com/news/state/oregon-was-first-sanctuary-community-to-respond-to-ice -subpoenas/article_6bb6beb2-5986-11ea-abc8-476ca58e0e6c.html [https://perma.cc/SQN9-DZ6Z].

53. Id.

54. Sophie Murguia, Oregon Has the Nation's Oldest Sanctuary Law. It Might Not Survive This Election., MOTHER JONES (Oct. 12, 2018), https://www.motherjones.com/politics/2018/10/oregonsanctuary-law-election/ [https://perma.cc/WR8P-G63E]; see also OR. REv. STAT. § 181A.820 (West 2020, Westlaw through 2020 Reg. Sess.).

55. Stephen W. Manning, A City \& County Framework for an Immigrant-Inclusive Vision of Oregon as a Response to the Proposed, Constitutionally Risky Actions by President-Elect Trump, INNOVATION L. LAB 6 (Dec. 31, 2016), https://innovationlawlab.org/wpcontent/uploads/2016/12/City-County-Oregon-Framework.vP2_.pdf [https://perma.cc/PP75-A8KN] (stating "Local Inclusive Resolutions should not be considered a 'sanctuary'....") (emphasis in original).

56. Wilson, supra note 52. 
anti-migrant initiatives. ${ }^{57}$ The law in Oregon has become a model for jurisdictions attempting to disrupt the Trump administration's vow to deport millions of migrants. ${ }^{58}$ Recently, Los Angeles adopted the formal moniker "City of Sanctuary" in line with the Oregon model through a formal declaration. ${ }^{59}$ The measure reaffirmed the city's commitment to "Special Order 40, which bars Los Angeles police officers from initiating contact with someone solely to determine whether they are in the country legally." 60 This was not the first time Los Angeles attempted to disentangle itself from federal immigration enforcement. In 2015, L.A. ended its $\S 287(\mathrm{~g})$ agreement with ICE. ${ }^{61}$ Oregon and Los Angeles highlight the differences between jurisdictions that use "sanctuary" to describe their very different noncooperation policies.

A relevant question underlying the fight between Trump and sanctuary jurisdictions is the foundation and reasoning behind either supporting or denigrating the increase of deportations. Trump and other conservativeleaning immigration policymakers seek to deport more individuals because they believe, among other rationales, that undocumented migrants increase crime. $^{62}$ These justifications for deportations are questioned by multiple studies analyzing the statistics regarding undocumented migrant crime. ${ }^{63}$ It is

57. Compare Andrew Selksy, Oregon Voters Deciding Fate of Pioneering Sanctuary Law, ASSOCIATED PRESS (Oct. 25, 2018), https://www.apnews.com/4631703afd0642acae11ed0b8a12472c [https://perma.cc/KK5Y-HRFN] (describing the racial profiling of Delmiro Trevino, an American born in Texas, leading to Oregon becoming America's first sanctuary state), with Jessica Taylor, Energized By Trump's Win, White Nationalists Gather To 'Change The World', NAT'L PUB. RADIO (Nov. 20, 2016, 11:38 AM), https://www.npr.org/2016/11/20/502719871/energized-by-trumps-winwhite-nationalists-gather-to-change-the-world [https://perma.cc/4FJT-ZYQ7] (describing the white nationalist movement and alt-right having a "psychic connection" with Trump, and their ultimate goal of "a return to the white origins of the country and protecting the white race.").

58. Wilson, supra note 52.

59. Dakota Smith \& Matthew Ormseth, It Took a While, but L.A. Formally Declares Itself a 'City of Sanctuary', L.A. TiMES (Feb. 8, 2019, 3:35 PM), https://www.latimes.com/local/lanow/lame-ln-city-of-sanctuary-cedillo-20190208-story.html [https://perma.cc/5EJL-C8Q7].

60. Id.

61. Adela de la Torre, Breaking the ICE: NILC Calls for ICE-Free Los Angeles, NAT'L IMMIGR. L. CTR. (May 12, 2015), https://www.nilc.org/2015/05/12/1-a-county-287g-pep-immigrationenforcement/ [https://perma.cc/MNR5-AQUB].

62. Jason Zengerle, How America Got to 'Zero Tolerance' on Immigration: The Inside Story, N.Y. TIMES MAG. (July 21, 2019), https://www.nytimes.com/2019/07/16/magazine/immigrationdepartment-of-homeland-security.html [https://perma.cc/42ZP-S73Y].

63. See RubÉn G. Rumbaut, Undocumented IMMigRATION AND RATES OF CRime AND IMPRISONMENT: POPULAR MYTHS AND EMPIRICAL REALITIES 2 (2008) (finding that perceptions about undocumented immigrants as criminals are "not supported empirically; instead, as demonstrated below, they are refuted by the preponderance of scientific evidence."); John Hagan \& Alberto Palloni, Sociological Criminology and the Mythology of Hispanic Immigration and Crime, 46 SOC. PROBS. 617, 617 (1999) (noting that "[o]ur sociological knowledge of crime is fragmented and ineffective in challenging and correcting mistaken public perceptions, for example, linking immigration and crime. These misperceptions are perpetuated by government reports of growing numbers of Hispanic 
worth noting that being present in the United States in violation of immigration law is not a crime, it is a civil offense. ${ }^{64}$ This distinction is important because, absent an understanding of this difference, every undocumented migrant would be a criminal based on their lack of documentation. According to the aforementioned statistics, those who oppose Trump's actions allege that his deportation policies are rooted in xenophobia, and are unrelated to the goal of decreasing crime. ${ }^{65}$ Those on the other side, however, continue to allege that the U.S. is a better place when the government is vigilant about immigration status. ${ }^{66}$ These disagreements between the two sides of the political aisle have manifested in the Trump administration using a litany of strategies to attempt to constrain sanctuary jurisdictions. Disputes, ranging from constitutional challenges, to funding conditions, ${ }^{67}$ to $\S 287(\mathrm{~g})$ Agreements,${ }^{68}$ and even political attacks, ${ }^{69}$ have followed Trump's continued attempts to reign in sanctuary cities.

\section{The Trump Administration's Immigration Cooperation Spending Conditions}

The Trump administration expanded its deportation regime, by promising to institute conditions on the receipt of federal grant dollars in an effort to

immigrants in U.S. prisons."); Elizabeth K. Stupi, Ted Chiricos \& Marc Gertz, Perceived Criminal Threat from Undocumented Immigrants: Antecedents and Consequences for Policy Preferences, 33 JUST. Q. 239, 239 (2014) (finding that "political ideology and education are the strongest predictors of perceived criminal threat.").

64. Merely being present and undocumented in the United States alone is not a crime. If there are other circumstances surrounding the undocumented presence, such as a prior deportation order or other crimes committed, then the presence may become a misdemeanor or a felony. See 8 U.S.C. $\S \S$ 1325-1326; Issue Brief: Criminalizing Undocumented Immigrants, ACLU 1 (Feb. 2010), https://www.aclu.org/other/issue-brief-criminalizing-undocumentedimmigrants [https://perma.cc/74HR-FHTU]. Moreover, Congress has expressly refused to pass the Border Protection, Antiterrorism, and Illegal Immigration Control Act of 2005, which would have made mere undocumented presence a felony. Id. at 2.

65. Trump is Lying about Immigrant Crime - and the Research Proves It, S. POVERTY L. CTR. (May 17, 2019), https://www.splcenter.org/news/2019/05/17/trump-lying-about-immigrant-crimeand-research-proves-it [https://perma.cc/55RG-4RVR] (concluding that "[r]esearch has long shown that recent immigrants are no more prone to criminality that native-born Americans. In fact, studies have suggested they are less so.").

66. Craig Kafura \& Bettina Hammer, Republicans and Democrats in Different Worlds on Immigration, CHI. COUNCIL ON GLOB. AFFs. (Oct. 8, 2019), https://www.thechicagocouncil.org/publication/lcc/republicans-and-democratsdifferent-worlds-immigration [https://perma.cc/C64M-CPM3].

67. See cases cited supra note 7 .

68. National Map of $287(\mathrm{~g})$ Agreements, supra note 31.

69. Zack Budryk, Trump Revived Attacks on Sanctuary Cities to Distract from Mueller Report Release: Report, THE HILL (Apr. 14, 2019, 8:13 PM), https://thehill.com/homenews/administration/438862-trump-revived-attacks-on-sanctuary-cities-todistract-from-mueller [https://perma.cc/U4A4-7LXJ]. 
enforce compliance with federal immigration goals. ${ }^{70}$ The administration's efforts "were smacked down hard by federal judges." "Specifically, the Trump administration attempted to invoke an executive order to "withhold funding from 'sanctuary cities' that limit cooperation with immigration authorities." 72 The Trump administration's objective in these cases was to punish the jurisdictions limiting their cooperation with ICE. ${ }^{73}$ One of the appeals in the Ninth Circuit regarding the executive order found that the judge, in invalidating the conditions, had gone too far and could not enjoin Trump's efforts nationwide. ${ }^{74}$ This led to a string of cases finding Trump's efforts to punish these jurisdictions unenforceable. ${ }^{75}$

One case in particular, City of Philadelphia v. Attorney General of the United States,${ }^{76}$ illustrates how the majority of these cases were decided. In City of Philadelphia, the city had received funding from the "federal Edward Byrne Memorial Justice Assistance Grant Program ("Byrne JAG") every year since the program's inception in 2006." ${ }^{\prime 77}$ Despite this long history, the Justice Department changed the conditions used to determine fund allocation for Fiscal Year 2017. ${ }^{78}$ The Department altered the conditions to include "greater coordination with federal officials on matters of immigration enforcement." 79 The new conditions included a Certification Condition (requiring the applicant to certify their compliance with sharing immigration status information) and a Notice Condition (requiring the applicant to notify DHS of an undocumented migrant's release date from their custody). ${ }^{80}$ Based on failure to satisfy these new conditions, the Attorney General withheld the funds from Philadelphia, and the city sued to enjoin this decision. ${ }^{81}$ The fundamental issue was whether Congress "empowered the Attorney General to promulgate the Challenged Conditions." ${ }^{\prime 2}$ The Third Circuit found that

\footnotetext{
70. Anita Kumar, Trump Administration Funds Sanctuary Cities Despite Pledge, Angering Supporters, MCCLATCHY DC $\quad$ May 29, 2018, AM), https://www.mcclatchydc.com/news/politics-government/white-house/article211897764.html [https://perma.cc/4GAF-YT7S].

71. Lind, supra note 40; see also cases cited supra note 7.

72. Associated Press, Trump Order to Withhold Funding from 'Sanctuary Cities' is Illegal, Court Says, PBS NEws Hour (Aug. 1, 2018, 2:37 PM), https://www.pbs.org/newshour/politics/trump-order-to-withhold-funding-from-sanctuary-cities-isillegal-court-says [https://perma.cc/XQ3G-3HHB].

73. $I d$.

74. Id.; City of Los Angeles v. Barr, 929 F.3d 1163, 1182-83 (9th Cir. 2019).

75. See cases cited supra note 7.

76. 916 F.3d 276 (3d Cir. 2019).

77. Id. at 279

78. Id.

79. Id.

80. Id. at 280

81. Id. at 279

82. Id. at 284 .
} 
Congress had not conferred the Attorney General with said power. ${ }^{83}$ In effect, the court stopped the administration from using the conditions related to immigration cooperation to deny funding to Philadelphia. This case did not reach an analysis under the Spending Clause. ${ }^{84}$

\section{The Spending Clause}

Nestled in the Trump administration's attempts to condition funding in order to punish sanctuary jurisdictions are Spending Clause issues. This clause sets limits for what the federal government can do in terms of spending. ${ }^{85}$ Courts have long held that the government is able to set conditions on the receipt of federal funds under the Clause. ${ }^{86}$ Yet, the power to condition funding is subject to restrictions - the spending program must be in pursuit of the general welfare, the condition must be unambiguous, and the condition cannot be unrelated "to the federal interest in particular national projects or programs." ${ }^{, 87}$ The last requirement, relatedness, is the subject of this paper's analysis.

The relatedness requirement (or, in other words, the "not-unrelated" requirement) comes primarily from two landmark cases-Massachusetts $v$. United States ${ }^{88}$ and Ivanhoe Irrigation District v. McCracken. ${ }^{89}$ Both of these cases were cited in what would become another landmark case, South Dakota v. Dole. ${ }^{90}$ Massachusetts $v$. United States was a case about a federal registration tax on aircraft. ${ }^{91}$ The State of Massachusetts owned a helicopter for police duties and refused to pay the tax. ${ }^{92}$ In response, the federal government levied the debt on one of the State's accounts, and Massachusetts filed suit to recover a refund. ${ }^{93}$ The primary issues the Court addressed involved the implied immunity of state governments and the Spending

\footnotetext{
83. Id. at 291 .

84. Id. at 284 (finding "if the Attorney General did not have that authority, then [the court] needn't reach the other claims.").

85. U.S. CONST. art. I, § 8, cl. 1.

86. See, e.g., South Dakota v. Dole, 483 U.S. 203, 206-07 (1987) ("Incident to [the Spending Power], Congress may attach conditions on the receipt of federal funds, and has repeatedly employed the power 'to further broad policy objectives by conditioning receipt of federal moneys upon compliance by the recipient with federal statutory and administrative directives."') (quoting Fullilove v. Klutznick, 448 U.S. 448, 474 (1980)).

87. Id. at 207 (quoting Massachusetts v. United States, 435 U.S. 444, 461 (1978) (plurality opinion)).

88. 435 U.S. 444, 461 (1978) (plurality opinion).

89. 357 U.S. 275,295 (1958).

90. 483 U.S. 203, 207-08 (1987).

91. Massachusetts, 435 U.S. at 446.

92. Id. at 452.

93. Id.
} 
Clause. ${ }^{94}$ Massachusetts argued the tax was invalid because the funding conditions were not directly related to their use. ${ }^{95}$ The Court noted case law consistently reinforced the notion that "the Federal Government may impose appropriate conditions on the use of federal property or privileges ... with conditions that are reasonably related to the federal interest in particular national projects or programs." 96 Under this analysis, the Court found that taxing the State was a permissible function of making the states pay a portion of the "costs of the benefits they enjoy from federal programs."

Massachusetts v. United States cites Ivanhoe Irrigation District v. McCracken ${ }^{98}$ as a case supporting appropriate conditions on federal funding. ${ }^{99}$ Ivanhoe discussed the Supreme Court of California's refusal to confirm two reclamation contracts citing the Reclamation Act of $1902 .{ }^{100}$ The Reclamation Act also included a repayment provision to the federal government for "funds expended on the construction of reclamation" projects. ${ }^{101}$ The Supreme Court of California held this part of the Act was invalid. ${ }^{102}$ In part, the challenge asserted that the federal government's general authority to "establish and execute" these projects was invalid, including the spending conditions attached to the projects. ${ }^{103}$ The Ivanhoe Court reversed the California Supreme Court on all issues, and, in pertinent part for this paper, noted that "the Federal Government may establish and impose reasonable conditions relevant to federal interest in the project." 104

The Court reiterated the arguments in these two cases when it articulated the current framework for conditional spending analysis in South Dakota v. Dole. ${ }^{105}$ Dole was a case about transportation funding. ${ }^{106}$ Congress passed a law ordering the Secretary of Transportation "to withhold a percentage" of a State's transportation funding if the State's minimum drinking age was less than 21. ${ }^{107}$ South Dakota challenged the law, in part, under the Spending

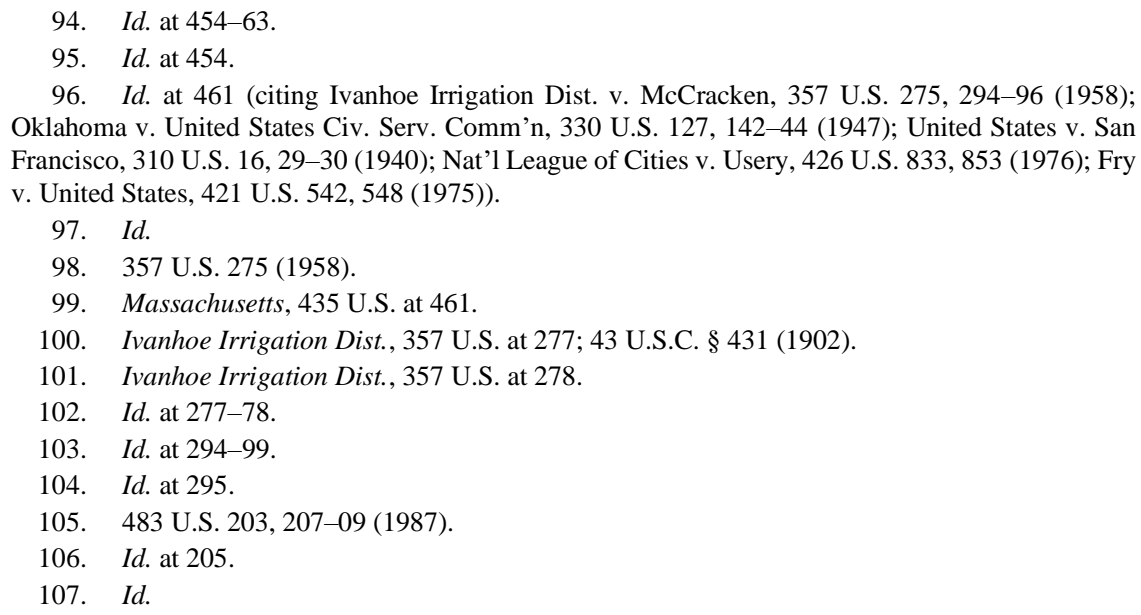


Clause. ${ }^{108}$ The Court upheld the transportation spending condition, in part, writing that conditions on federal grants "might be illegitimate if they are unrelated 'to the federal interest in particular national projects or programs." "109 The Court did not analyze the relatedness of the condition to the use of the funds because South Dakota never contended the conditions were unrelated to transportation. ${ }^{110}$

However, Justice O'Connor, in her dissent, fully analyzed the relatedness question. ${ }^{111}$ O'Connor differed from prior case law in how she articulated the relatedness requirement. She wrote that the condition "must be reasonably related to the purpose of the expenditure" 112 whereas the majority wrote that the condition might be "illegitimate if they are unrelated" to the federal goals. ${ }^{113}$ This difference, although semantic, led Justice O'Connor to find that the spending condition was invalid because it was not reasonably related to the purpose of the funding. ${ }^{114}$ She cited the same two cases as the majority did-Massachusetts and Ivanhoe Irrigation-but found that the transportation spending law was both over- and under-inclusive. ${ }^{115}$ Another way to articulate the difference between the majority's holding and O'Connor's dissent is a comparison with the different levels of scrutiny the Court has applied to other areas of constitutional law. Generally, when the constitutionality of a law is challenged before the Supreme Court under the Equal Protection Clause, the Due Process Clause, or the First Amendment, the Court scrutinizes the law using three different levels of scrutiny: rational basis, intermediate scrutiny, and strict scrutiny. ${ }^{116}$ Under rational basis, or "minimum rationality" view, the law asks whether the condition is rationally related to legitimate government interests. ${ }^{117}$ Under the intermediate scrutiny level, "the legislation must be substantially related to advancing important or substantial governmental interests ...."118 Finally, under the strictest test, strict scrutiny, the law must directly advance a compelling government

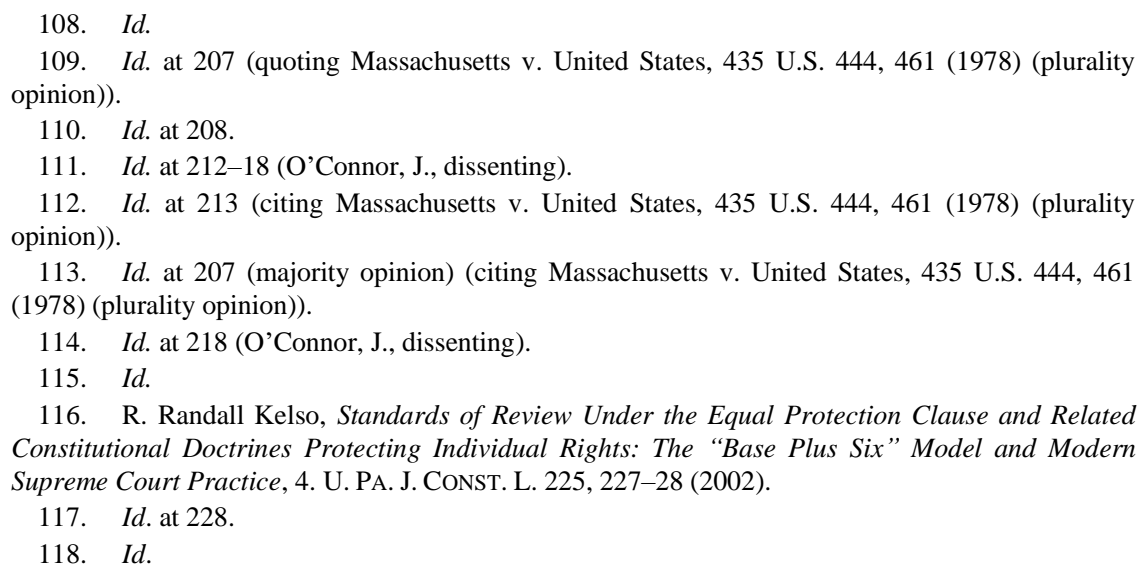

116. R. Randall Kelso, Standards of Review Under the Equal Protection Clause and Related Constitutional Doctrines Protecting Individual Rights: The "Base Plus Six" Model and Modern Supreme Court Practice, 4. U. PA. J. Const. L. 225, 227-28 (2002).

117. Id. at 228.

118. Id. 
interest. ${ }^{119}$ Although the Supreme Court generally does not reference the levels of scrutiny directly, it seems the majority in Dole only employs a rational basis test for whether the condition is related to the goals of the grant. ${ }^{120}$ On the other hand, O'Connor uses a test more similar to intermediate scrutiny when focusing more on the condition's substantial relation to the purposes of the funding. ${ }^{121}$ The levels of scrutiny are helpful in identifying the difference in approach between the majority's opinion and Justice O'Connor's dissent and are also helpful in identifying a more rigorous analysis for the relatedness requirement.

These conditional Spending Clause issues have filtered through to the instant case subject to this paper's analysis-focusing on Trump's promise to defund all sanctuary jurisdictions.

\section{E. The Los Angeles Case}

Trump was not able to make good on his promise to defund all sanctuary jurisdictions, even outside of the court context. ${ }^{122}$ Overall, Trump attempted to follow through on his promise by focusing on two grant programs - the Edward Byrne Memorial Justice Assistance Grant (JAG) program and the Community Oriented Policing Services (COPS) program. ${ }^{123}$ Republicans focused on introducing "legislation that sought to strip jurisdictions violating Section 1373 of funding under two federal programs - the ... (JAG) program ... and the ... (COPS) program."124 The latter program is at the center of the Los Angeles case. ${ }^{125}$

The federal government established the COPS grant program under the Public Safety Partnership and Community Policing Act of 1994. ${ }^{126}$ Originally, the COPS grant was intended to increase the amount of law enforcement officers in communities to improve communication and cooperation between the communities and officers, in what the Act calls

119. Id.

120. While the majority does not directly reference a level of scrutiny, by upholding this restriction, it recognizes drinking age is not unrelated to transportation safety, suggesting a rational basis standard of review. Dole, 483 U.S. at 208-09.

121. Id. at 213-14 (O'Connor, J., dissenting) (noting that setting a minimum drinking age is "not sufficiently related to interstate highway construction to justify so conditioning funds appropriated for that purpose.").

122. See Kumar supra note 70.

123. See Press Release, Office of the Attorney General of Connecticut, Attorney General Tong Joins Coalition of 15 AGs in Brief to Protect Critical Law Enforcement Funding from Trump Administration's Unconstitutional Overreach (May 30, 2019).

124. Annie Lai \& Christopher N. Lasch, Crimmigration Resistance and the Case of Sanctuary City Defunding, 57 Santa Clara L. Rev. 539, 552 (2017).

125. City of Los Angeles v. Barr, 929 F.3d 1163, 1169-70 (9th Cir. 2019).

126. Id. at 1183 (Wardlaw, J., dissenting). 
"community partnerships."127 The Act also created the COPS Office, under the DOJ, to administer the COPS program. ${ }^{128}$

In the vein of pursuing the goal of increasing police-community relationships, the federal grant dollars were allocated to "hire community policing professionals, develop and test innovative policing strategies, and provide training and technical assistance to community members, local government leaders, and all levels of law enforcement." "29 The dollars can be put toward a litany of purposes; including, "hiring or re-hiring community policing officers; procuring law enforcement equipment, technology, or support systems; or establishing school-based partnerships between local law enforcement agencies and local school systems." ${ }^{130}$ Over the lifetime of the grant, the funding has vacillated between these purposes, but all the initiatives have purported to focus on improving community relationships. ${ }^{131}$

Then-Attorney General Sessions subsequently converted the purpose of the COPS grant program to "divert federal funds ... to press state and local police into federal immigration enforcement" in an effort to employ this program as another tool for the Trump administration. ${ }^{132}$ The majority in the City of Los Angeles case found the purpose of the COPS program to be broader, and characterized the grant's goals as combatting crime and disorder problems, rather than solely focused on community-oriented policing. ${ }^{133}$

In order to receive funding under the grant, each city must submit an application to the DOJ for review. ${ }^{134}$ In the application, there is a series of questions in which the applicant city can prove why it qualifies to receive the grant dollars. ${ }^{135}$ The application, among other requirements, asks each applicant to identify its strategies for remedying crime and disorder problems, as well as asking each applicant to identify a problem or focus area. ${ }^{136}$ There are eight focus areas to choose from, one of which is a focus on "illegal immigrations." 137 The guidelines for the "illegal immigration" focus area state many familiar ways the Trump administration has preferred to engage

\footnotetext{
127. Id.

128. Nathan James, Cong. Rsch. Serv., IF10922, Community Oriented Policing SERVICES (COPS) PROGRAM 1 (2019).

129. Id.

130. Id.

131. Id.

132. City of Los Angeles v. Barr, 929 F.3d 1163, 1183 (9th Cir. 2019) (Wardlaw, J. dissenting).

133. Id. at 1169 (majority opinion).

134. Id.

135. Id. at 1170 .

136. Id.

137. Id. at 1170-71. The eight focus areas are illegal immigrations, child and youth safety, drug abuse education, prevention and intervention, homeland security problems, nonviolent crime problems and quality of life policing, building trust and respect, traffic/pedestrian safety problems, and violent crimes problems. Id.
} 
with localities on immigration, including a "focus on partnering with the federal law enforcement to address illegal immigration for information sharing, [§] 287(g) partnerships, task forces and honoring detainers." ${ }^{138}$ After "evaluat[ing], scor[ing], and rank[ing]" the applications, the DOJ grants funds to cities with the highest scores. ${ }^{139}$ Among other criteria, such as the need for federal dollars and the application's commitment to increasing communityoriented policing, the DOJ "scores applicants on how their proposals relate to that year's federal goals." "140 The City of Los Angeles challenged the fact that in 2017 the DOJ "gave additional points to applicants that focused on ... violent crime, homeland security, and control of illegal immigration." 141

Due to limited funding, not every city that applied could receive grant dollars. ${ }^{142}$ One-third of the large jurisdictions and roughly fourteen percent of small jurisdictions received grant funding. ${ }^{143}$ The DOJ awarded bonus points to jurisdictions that committed to cooperating with the federal government on combatting illegal immigration. ${ }^{144}$ Seven of the applicants reported illegal immigration as their focus area, and two received grants. ${ }^{145}$ In both large and small jurisdictions, over sixty percent of applications that received funding submitted a "Certification of Illegal Immigration Cooperation." 146 The DOJ announced this "bonus certification" two months after the 2017 applications were due. ${ }^{147}$ Upon announcing the 2017 funding awards, then-Attorney General Sessions stated that "eighty percent of the grantees have agreed to cooperate with federal immigration authorities in their detention facilities" and he "applaud[ed grantees'] commitment to the rule of law and to ending violent crime, including violent crime stemming from illegal immigration." "148 The plaintiff in City of Los Angeles v. Barr chose "building trust and respect" as its focus area and did not select "illegal immigration" or sign the Cooperation Certification. ${ }^{149}$ When Los Angeles was not awarded grant dollars, it filed "a complaint seeking to enjoin [the]

\footnotetext{
138. Id. at 1171 (footnotes omitted)

139. Id.

140. Id.

141. Id.

142. Id. at 1172 (noting Congress allocated around "\$98.5 million for grants," and "applicants requested almost $\$ 410$ million.”).

143. Id. Note the statute governing this grant program differentiates between "large" and "small" jurisdictions. See 34 U.S.C. $§ 10382$. Small jurisdictions are those with a population of less than 50,000. Id. at $\S 10382(\mathrm{~d})(1)$.

144. City of Los Angeles, 929 F.3d at 1190 (Wardlaw, J., dissenting).

145. Id. at 1172 (majority opinion).

146. Id at $1171-72$ (noting that 19 of the 30 large jurisdictions and 124 of the 149 small jurisdictions that received funding reported a Certification).

147. Id. at 1190 (Wardlaw, J., dissenting).

148. Id. at 1191 (internal quotations omitted) (alteration in original).

149. Id. at 1172 (majority opinion).
} 
DOJ's practice of awarding points to applicants that selected the illegal immigration focus area and to applicants that completed a Certification related to illegal immigration." 150

The district court held that the bonus points and application procedures executed by Sessions and the DOJ were not lawful conditions. ${ }^{151}$ On appeal, the Ninth Circuit discussed three different issues: (1) a separation of powers challenge, (2) a Spending Clause challenge, and (3) an Administrative Procedure Act challenge. ${ }^{152}$

The Ninth Circuit concluded that the bonus points awarded through both a focus area on immigration and the Certification were not violative of the Spending Clause. ${ }^{153}$ It noted that the federal government has the ability to condition the states' receipt of federal funds in order to persuade the states to take actions Congress could not require them to take otherwise. ${ }^{154}$ Yet, this power to condition is not unlimited, but is subject to four limitations: (1) the condition must support the general welfare, (2) it must be unambiguous, (3) it cannot force states to take unconstitutional actions, and (4) it "may not impose conditions on federal grants that are unrelated to the federal interest in particular national projects or programs." ${ }^{\text {"155 }}$ This final prong, the relatedness prong, is the subject of this Comment's analysis.

On said prong, the City of Los Angeles majority stated that the standard for relatedness is not demanding, and the prior case law has been cursory, noting that "the Court has never struck down a condition on federal grants based on this relatedness prong." 156 In its analysis, the Ninth Circuit was quick to dismiss the relatedness analysis, indicating that the condition "meets the low bar of being germane to the federal interest in providing the funding to "address crime and disorder problems, and otherwise ... enhance public safety." "157 The majority and the dissent applied this relatedness analysis primarily under the separation of powers challenge to the procedure. ${ }^{158}$ The majority found the goals of the Act to be "broad" and noted that the bonus

\footnotetext{
150. Id.

151. Id. at 1169. The majority also discussed whether the application procedures were truly harming Los Angeles and whether they are a condition. Id. at 1173-76. These issues are outside of the scope of this paper, and this paper assumes, as the majority held, that they are a condition to be relevantly analyzed by the Spending Clause.

152. Id. at 1172. Outside of the Spending Clause, the other two issues are beyond the scope of this paper.

153. Id. at 1176 .

154. Id. at 1174 (citing Nat'l Fed'n of Indep. Bus. v. Sebelius, 567 U.S. 519, 576 (2012).

155. City of Los Angeles, 929 F.3d at 1174-75 (internal quotations omitted) (citing South Dakota v. Dole, 483 U.S. 203, 207-08 (1987)); see also NOLAN, ET AL., supra note 13, at 28-35.

156. City of Los Angeles, 929 F.3d at 1175.

157. Id. at 1176 (alteration in original).

158. Id. at 1177-81. Id. at 1191-93 (Wardlow, J., dissenting).
} 
points were "entirely consistent" with said broad goals. ${ }^{159}$ On the other hand, the dissent explored the history of community-policing in depth, defining the goals more narrowly, by looking at the context of the COPS program itself. ${ }^{160}$ The dissent found the bonus points inconsistent with this narrower construction of the Act's goals. ${ }^{161}$ Neither opinion reached the relatedness prong with any prolific discussion. As the dissent stated, "[w]hichever of the three violations we consider, however, the fundamental point is the same: Congress did not authorize the Attorney General to act with unfettered discretion in imposing conditions for COPS grants unrelated to communityoriented policing." 162

\section{RELATEDNESS ANALYSIS}

As the majority in the City of Los Angeles case noted, the relatedness prong of the Spending Clause of the Constitution has only been cursorily discussed in the previous case law. ${ }^{163}$ Yet, this fact is inconsistent with the purpose behind the relatedness prong. The fact that the Trump administration is using federal grant programs to pursue unrelated policy goals presents a unique opportunity to analyze the relatedness prong with more force. This Comment's analysis focuses on two essential points. The first is that the Supreme Court's limited precedential analysis of the relatedness prong must be set aside, so that today's courts can give it more force. The second is that the Trump administration's change in the application process for the COPS grant program likely would not pass a newly invigorated relatedness test.

\section{A. Reinvigorating the Relatedness Prong}

The relatedness prong of the Spending Clause should be reinvigorated. In the context of a challenge to the Bail Reform Act of 1984, Justice Marshall declared, in his scathing Salerno dissent:

Our Constitution ... can shelter us forever from the evils of... unchecked power. Over 200 years it has slowly, through our efforts, grown more durable, more expansive, and more just. But it cannot protect us if we lack the

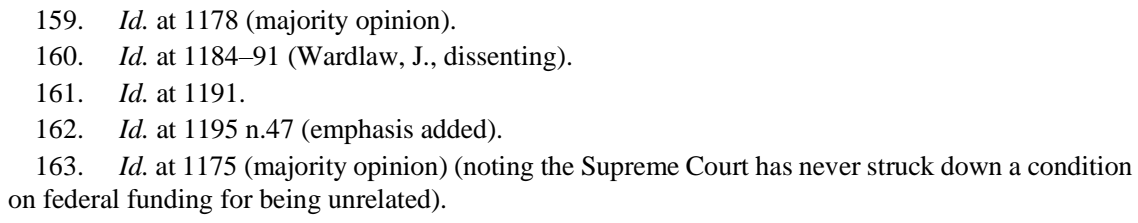


courage, and the self-restraint, to protect ourselves. ${ }^{164}$

Although this quote arose in a criminal law context, Justice Marshall's powerful words propel a basis for employing the relatedness clause with more than perfunctory force. The Constitution was, indeed, set up to restrain unchecked government power. Trump's actions have set the stage for the Constitution to serve this purpose. ${ }^{165}$ In order to understand the importance of the relatedness prong against this constitutional backdrop, historical context is key.

The Dole test, historically, may have been intended to be more rigid than how it has been applied in recent years. ${ }^{166}$ The current jurisprudence has made it almost impossible to invalidate any condition challenged, ${ }^{167}$ yet the traditional debate behind this prong was far more contentious than contemporary hasty analyses. The origins of the traditional views on how to apply the relatedness prong, can be traced to Alexander Hamilton and James Madison. ${ }^{168}$ Although Madison and Hamilton's debate was more focused on the Spending Clause in general, their arguments directly relate to relatedness prong issues. Madison did not think the Spending Clause should be read as a "separate grant of power" but supported a "narrow" construction, implying the importance of the four qualifications under the Clause. ${ }^{169}$ Hamilton, on the other hand, favored a strong federal government and recognized the Clause as a "separate and distinct" grant of power, implying opposition to a more demanding spending test. ${ }^{170}$ These positions were argued before the Supreme Court in United States v. Butler, where the Court appeared to adopt the Hamiltonian view, allowing an expanded version of the Spending Clause. ${ }^{171}$ It is important to note that their debate was far broader than this paper's specific focus on one prong of the Spending Clause test-it was about Congress' exercise of the spending power in general. Despite this, the debate and Butler still highlight a salient fact - the discussion of the Spending Clause

164. United States v. Salerno, 481 U.S. 739, 767 (1987) (Marshall, J., dissenting).

165. See generally Daniel S. Cohen, A Gun to Whose Head? Federalism, Localism, and the Spending Clause, 123 DICK. L. REV. 421, 428-35 (2019) (discussing the Trump administration's action towards sanctuary cities and the resulting constitutional implications).

166. Tonnis H. Venhuizen, Note, United States v. American Library Association: The Supreme Court Fails to Make the South Dakota v. Dole Standard A Meaningfull [sic] Limitation on the Congressional Spending Powers, 52 S.D. L. REv. 565, 598-600 (2007) (describing the Dole standard as "toothless").

167. Id. at 583-84 (discussing how Congress and the courts have relied on the Hamiltonian view, which favors a less-restrictive Spending Clause); City of Los Angeles, 929 F.3d at 1175 (noting the Supreme Court has never struck down a condition based on unrelatedness).

168. Venhuizen, supra note 166 at 582.

169. Id.

170. Id.

171. 297 U.S. 1, 86-88 (1936). 
has not always been so cursory.

Although the Court in recent history has held otherwise, a more rigid construction of this test is consistent with the rationale behind the relatedness prong from its inception and is backed by historical and legal support. The relatedness prong has an important history in the Constitution. It is meant to restrict overbroad government power, and maintain the balance of power in the federal system. ${ }^{172}$ As the National Conference of State Legislatures (NCSL) wrote in its amicus brief in Dole "[u]nrelated spending conditions can destroy state autonomy by permitting Congress to legislate outside the limits of its delegated regulatory powers. Such conditions constitute a fundamental subversion of our constitutional system, which bestowed limited powers on the federal government and reserved all other regulation of private activity to the States." "dramatic rise" in federal programs and agencies since Dole. ${ }^{174}$ While the NCSL brief warns of Congress' addition of unrelated spending conditions, they did not anticipate the possibility of the President independently conditioning funds through agency powers under his control. Given the massive scope of federal programs, if the President is able to command agencies and programs to condition their funds on unrelated presidential objectives, the President is effectively able to bypass the role of working with Congress. Therefore, the President is able to implement policies balanced against state protections-abrogating the careful constitutional system in place.

Relatedness ensures that the President and her administration are unable to dominate states' abilities to receive funding, conditioned commensurate with their own goals that Congress did not contemplate. If unenforced, the President is able to cherry-pick any congressionally-approved spending grants and enforce completely unconnected policy objectives as a condition to receiving said funds, depending on the ability of the President or agencies to impose conditions not specified by statute. The coercive nature of these actions matches some of the concerns discussed in National Federation of Independent Businesses v. Sebelius. ${ }^{175}$ In this case, when discussing the Spending Clause implications of the Affordable Care Act, the States contended that the Medicaid expansion exceeded congressional authority and was coercive. ${ }^{176}$ In reviewing this issue, the Court noted that the Spending

172. Brief of the National Conference of State Legislatures et al. as Amici Curiae Supporting Petitioner at 1, South Dakota v. Dole, 483 U.S. 203 (1987) (No. 86-260).

173. Id. (emphasis added).

174. Id. (quoting WORKING GRP. ON FEDERALISM, THE STATUS OF FEDERALISM IN AMERICA, at $30(1986))$.

175. 567 U.S. 519 (2012).

176. Id. at 540 . 
Clause is like a "contract," where the State "voluntarily and knowingly accepts the terms." 177 By forcing the States to adopt changes to their Medicaid programs under a threat of withholding funding, the States alleged that this was coercive and did not comport with the idea of the contract. ${ }^{178}$ In simpler terms, this is not what the states signed up for.

A similar line of reasoning belies the argument for reinforcing the relatedness standard. Relatedness is key to avoiding a bait-and-switch-style federal government that uses states' and localities' reliance on programs to coax them into pursuing federal goals unrelated to said programs. Arguably, these fears are currently being played out by the Trump administration in the immigration context. ${ }^{179}$ It is possible that the "relatedness prong could be narrowed to require that conditions be germane to the purpose of the funding." " is not enough to be considered coercive, but the same logic behind the two situations applies.

In subsequent landmark cases, the language the Court used could also provide a basis for strengthening the relatedness prong. ${ }^{181}$ For example, in Dole, the Court cited to Massachusetts v. United States to find that relatedness was a limitation on the federal government's power to condition funding. ${ }^{182}$ In Massachusetts v. United States, the Court noted the requirement at issue in the case was "reasonably related" because it was "closely related to the federal interest in recovering costs from those who benefit." "The Ivanhoe case, cited by the Court in both Dole and Massachusetts v. United States, found that "the Federal Government may establish and impose reasonable conditions relevant to [the] federal interest in the project ...." ${ }^{184}$ The very language of the precedential cases' analyses - "closely related"185 and "relevant"186_ demands a higher standard than the "low bar" used in the more contemporary

\footnotetext{
177. Id. at 577 (citing Pennhurst State Sch. \& Hosp. v. Halderman, 451 U.S. 1, 17 (1981)). 
cases, including City of Los Angeles. ${ }^{187}$

The way the Dole majority wrote the relatedness requirement, when juxtaposed against the language in the cases the Court relied on to articulate it, seems to fundamentally alter the test. It removes any language such as "closely", "relevant", or "reasonably related" and replaces it with a question phrased in the negative-is it unrelated? ${ }^{188}$ This phrasing takes the onus off of the stringency that prior case law seems to place on the requirement, arguably reducing the standard to a mere rational basis review.

The "low bar" reasonableness approach does not comport with the reasons underlying the reasonableness prong, and Justice O'Connor's dissent in Dole relied on the notion that relatedness should be a stronger obstacle, more similar to intermediate scrutiny. ${ }^{189}$ In her dissent, Justice O'Connor wrote:

If the spending power is to be limited only by Congress' notion of the general welfare, ... the Spending Clause gives power to the Congress to tear down the barriers, to invade the states' jurisdiction, and to become a parliament of the whole people, subject to no restrictions save such as are selfimposed. This, of course, as Butler held, was not the Framers' plan and it is not the meaning of the Spending Clause. ${ }^{190}$

Her dissent provides analytical support for the idea that conditions must be subject to a more rigorous relatedness analysis, otherwise the federal government can invade spaces where it ought not. ${ }^{191}$ Primarily, Justice O'Connor wrote that the condition must be "reasonably related" to the goals of the act, arguing that a minimum drinking age was far too "attenuated" to be related to highway funding. ${ }^{192}$ She analyzed that even the "possible connection" of highway safety did not have anything to do with "the expenditure of funds for highway construction"-functionally elevating the scrutiny of relatedness towards intermediate or even strict scrutiny. ${ }^{193}$ As a part of her analysis of whether the condition was "reasonably related", her dissent used an over- and under-inclusive test. ${ }^{194}$ She wrote that if the goal of

\footnotetext{
187. City of Los Angeles v. Barr, 929 F.3d 1163, 1176 (9th Cir. 2019).

188. South Dakota v. Dole, 483 U.S. 203, 207 (1987).

189. Id. at 212-18 (O'Connor, J., dissenting).

190. Id. at 217 (internal quotations and citations omitted).

191. Id. at $217-18$.

192. Id. at 215-18.

193. Id. at 218.

194. Id. at 214-15.
} 
the challenged minimum drinking age is to stop drunk people from driving "it is far too over and under-inclusive. It is over-inclusive because it stops teenagers from drinking even when they are not about to drive on interstate highways. It is under-inclusive because teenagers pose only a small part of the drunken driving problem in this Nation." 195

Justice O'Connor's dissent is reinforced when reviewing some of the cases where courts have upheld spending conditions "without a clearly explained relationship to the underlying legislation." ${ }^{196}$ For example, in order for states to receive federal funds under the Temporary Assistance to Needy Families Program, they must maintain an automated child support enforcement system. ${ }^{197}$ Further, in order to receive Medicaid funds, Congress imposed a condition that states must provide emergency medical services to undocumented migrants. ${ }^{198}$ Additionally, in order to receive federal funds for prisons and state institutions, the state must comply with a heightened standard to protect religious freedom for prisoners. ${ }^{199}$ Regardless of the commendable goals the previous conditions contain, it is hard to argue that they are related to the underlying programs. ${ }^{200}$ This emphasizes the fact that the relatedness prong is currently a very low bar to overcome, and rarely is analyzed with any vigor. ${ }^{201}$

Moreover, although states desire to enforce commendable conditions, the true justification and debate for strengthening the relatedness prong arises when the conditions are not as commendable. The Framers wrote the clause with the fear of a tyrannical government looming over them, and thus it should be strengthened with that fear in mind. This notion is also playing out in other related contexts, where more liberal-leaning lawmakers are now discussing federalism's importance in the face of Trump's policies creating "[h]ostility toward immigrants" and even, in some cases, violence. ${ }^{202}$ On the whole, these ideas highlight the importance of reinforcing the relatedness clause, which is the first step in arguing that the City of Los Angeles case could not pass a reinforced relatedness test.

Importantly, not all contemporary cases have upheld unrelated spending

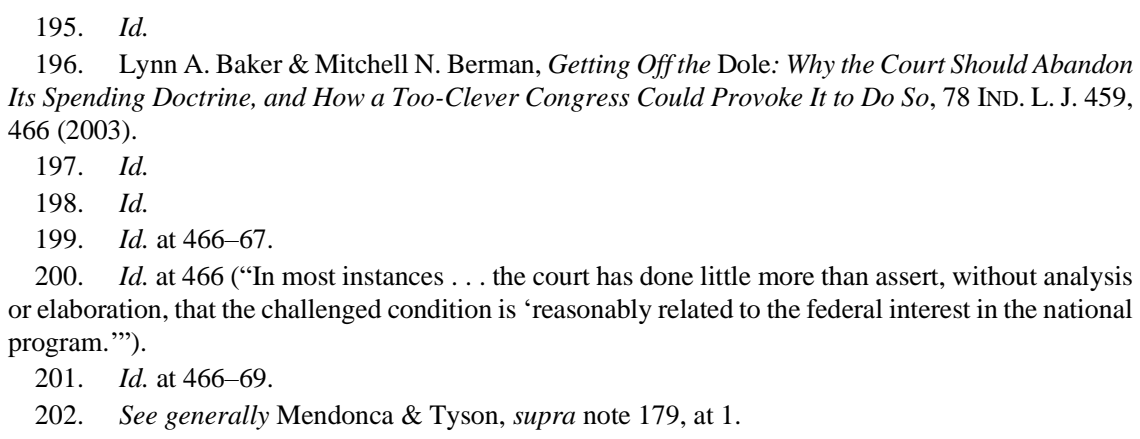


conditions. Despite the fact that "the [Supreme] Court has never struck down a condition on federal grants based on this relatedness prong," 203 lower courts have reviewed the prong with more force. For instance, in Guillen v. Pierce County, the parties argued about whether the federal interest in safety enhancement equipment could be a bar on discovery of state accident reports. ${ }^{204}$ In this case, the Supreme Court of Washington found "no valid federal interest in the operation of the federal safety enhancement program is reasonably served by barring the admissibility and discovery in state court of accident reports." 205 Although this case was later reversed on other grounds by the Supreme Court of the United States, ${ }^{206}$ the language serves as a potential beacon of reinvigoration.

Another example involves the City of Philadelphia and the JAG Program, where the City argued that a program focusing on local criminal enforcement could not be related to goals of civil federal immigration enforcement. ${ }^{207}$ Although the Attorney General sought to argue that the criminal law and immigration law intertwined, the federal district court found that "the argument that enforcement of federal immigration laws is related to [the program's criminal] objective is unsustainable.... The federal interest in enforcing immigration laws falls outside of the scope of the Byrne JAG program." ${ }^{208}$ In all, these cases provide brief examples of the relatedness prong being applied more stringently. Thus, tightening the relatedness prong remains possible, yet unlikely.

The relatedness prong of the Spending Clause in the Constitution should be reinforced in light of its history buttressed against its cursory treatment in the past. Because the federal government has expanded its power while simultaneously starting to place unrelated conditions on grants of federal dollars to make states pursue its policy goals, the time for the courts to reinvigorate and elevate the scrutiny applied to the relatedness prong is now. Coupling the interest of the states in balancing their power with the federal government and the prong's purpose of restraining federal power, along with the few cases and dissents that have begun to outline the previously-avoided relatedness test, the prong should be strengthened to better serve the Spending Clause's original purpose.

\footnotetext{
203. City of Los Angeles v. Barr, 929 F.3d 1163, 1175 (9th Cir. 2019).

204. Guillen v. Pierce Cnty., 31 P.3d 628, 632-33 (Wash. 2001) (en banc), rev'd in part on other grounds, 537 U.S. 129 (2003).

205. Id. at 651 (emphasis added).

206. See Pierce Cnty. v. Guillen, 537 U.S. 129, 147-48 (2003).

207. City of Philadelphia v. Sessions, 280 F. Supp. 3d 579, 591 (2017).

208. Id. at 642 .
} 


\title{
B. Applying the Test
}

If the relatedness prong were tightened, actions like the COPS program's bonus point system for immigration-complying jurisdictions would likely be invalidated. In contrast to the majority in Dole,

\begin{abstract}
Justice O'Connor ... would have required a much closer fit between the funding condition and the proclaimed federal interest. Thus, she, unlike the Dole majority, would not sustain a funding condition found to be over- or underinclusive. She therefore would have invalidated the funding condition on the ground that it was not sufficiently related to interstate highway construction. ${ }^{209}$
\end{abstract}

In parsing out the relatedness test, there are a few ways to show whether the condition is related to the goals of the federal program. The main issue is whether the condition sufficiently relates to the federal interest of the project on its merits. One way to test this is by using Justice O'Connor's over- and under-inclusiveness analysis. ${ }^{210}$ Yet, not all cases employing a relatedness analysis have used O'Connor's over- or under-inclusiveness analysis, ${ }^{211}$ suggesting there is more than one possible way to show that the condition is related. Another way is to compare the goals of the program with the condition as defined by the majority, under a question of whether they reasonably relate. Functionally, the comparison test uses a broader goal definition to still reveal the lack of relatedness. Finally, borrowing from other types of jurisprudence, such as takings clause litigation, congruence and proportionality can produce another possible test to elevate the relatedness analysis. When applied to the COPS grant program's bonus points, the condition on the receipt of federal funds likely would not pass any of the tests.

209. Kansas v. United States, 24 F. Supp. 2d 1192, 1198 (D. Kan. 1998) (internal citations and quotations omitted).

210. Id.; see supra note 195 and accompanying text.

211. See generally Massachusetts v. United States, 435 U.S. 444, 460-62 (1978) (plurality opinion) (finding the funding condition permissible because it did not greatly interfere with state sovereignty); Ivanhoe Irrigation Dist. v. McCracken, 357 U.S. 275, 295 (1958) (finding the condition related because the condition regulates that which the government subsidizes and does not deprive claimants of any rights to property or water); Pierce Cnty., 31 P.3d at 651, rev'd in part on other grounds, 537 U.S. 129 (2003) (finding the condition unrelated because the federal funding had "strings attached" that interfered with the "basic functioning of state government"); City of Philadelphia, 280 F. Supp. 3d at 642 (finding the condition unrelated after looking to the statutory purpose). 


\section{Inclusiveness Analysis}

The easiest way to perform the analysis is to review the majority's holding in City of Los Angeles and then inspect the reasons to rebut it. The majority found that the bonus points awarded for certain jurisdictions were valid because immigration cooperation was related to the goals of reducing crime and disorder, as well as increasing public safety. ${ }^{212}$ The way the majority defined the goals of the program were far broader than the dissent, and were also manifestly ahistorical and incorrect. ${ }^{213}$ Notably, the very starting point for the majority's analysis began with the wrong goals in mind. Even if the relatedness clause is a low bar to pass, that does not mean the analysis defining the goals of the federal interest must be cursory as well. As the dissent pointed out, the goals of the program are best viewed through a lens of how the program's dollars have actually been used. ${ }^{214}$ Here, the COPS program's funds have been dispersed to aid community policing functions, and at times to invest into officer training. ${ }^{215}$ Specifically, Congress enacted the Act establishing the COPS grant program in order to "strengthen the relationship between the police and the people they serve, fostering trust and increasing accountability." 216

The problem within the majority's analysis is that it takes a benefit of the program and turns it into the program's goal in order to fashion a more sweeping umbrella under which immigration cooperation can fall-but this is improper. An increased level of scrutiny makes the impropriety even clearer. Decreasing crime and disorder problems may be a tangential benefit and result of improving police and community relationships, but it is not the real goal the COPS program seeks to address.

A review of the previous case law makes this point even more fatal to the majority's holding. For instance, in Dole, the Court noted that "safe interstate travel" was a main purpose of the reason highway funds were expended. ${ }^{217}$ Moreover, even lower courts find an examination of the "rationale" behind the implementation of a program is key-specifically the backdrop and circumstances that produced the legislation affect relatedness. ${ }^{218}$

\footnotetext{
212. City of Los Angeles v. Barr, 929 F.3d 1163, 1169-70 (9th Cir. 2019).

213. Id. at 1192 (Wardlaw, J., dissenting) ("The federal immigration preferences flout the clear congressional purpose of COPS grants - to promote partnership between local law enforcement and the communities they serve - by instead favoring partnerships between local police and federal immigration authorities.").

214. Id.

215. Id. at 1183 .

216. Id. at 1186 (quoting H.R. REP. No. 103-324, at 7 (1993)).

217. See South Dakota v. Dole, 483 U.S. 203, 208 (1987).

218. Hodges v. Shalala, 121 F. Supp. 2d 854, 874 (D.S.C. 2000) (analyzing the legislative purpose behind child support enforcement funds and TANF funds).
} 
Without reviewing the backdrop of the creation of the COPS program, it may seem that the overarching goals the majority isolates are the primary goals of the program, but this limited analysis ignores the backdrop behind the COPS program, its rationale, and the way the recipients use the funds. Both the grant's own milieu and the way it has historically been expended center on increasing cooperation between police officers and their communities, because, prior to its creation, "unstable social conditions" led to an "erosion of confidence" between communities and officers. ${ }^{219}$ The majority, while even citing to the same place in Dole as the dissent, ${ }^{220}$ fails to follow Dole's command - to look at the "main purposes for which . . . funds are expended." 221 The majority may look at a vague description of the main purposes (albeit still arguable that those are purposes and not just benefits), but it fails to actually do the rigorous analysis that the dissent engages in to show what goals the funds have actually been allocated to achieve. Thus, the proper description of the goals lies with the dissent-a goal to increase cooperation between communities and police, not merely to decrease crime and disorder. ${ }^{222}$

Even if the majority's cursory, limited analysis of the goals was accurate, other persuasive authority on the question of relatedness would find the conditions unrelated. For example, the City of Philadelphia case noted any possible connection between civil immigration enforcement and deterring crime would not be enough to satisfy a stricter relatedness standard. ${ }^{223}$ Further, immigration cooperation is both over- and under-inclusive in serving the goals of reducing crime and disorder, as well as increasing public safety. Justice O'Connor's discussion of over- and under-inclusiveness in Dole clearly shows how the condition imposed is unrelated to the purported goals. ${ }^{224}$ Justice O'Connor wrote that the transportation spending conditions' goal of reducing drunk driving "is far too over and under-inclusive. It is overinclusive because it stops teenagers from drinking even when they are not about to drive on interstate highways. It is under-inclusive because teenagers pose only a small part of the drunken driving problem in this Nation."225 This dissenting opinion is a strong example of how the over and underinclusiveness test can be applied to other conditions.

For example, the condition in the City of Los Angeles is over-inclusive

219. City of Los Angeles, 929 F.3d at 1184 (Wardlaw, J., dissenting).

220. Id. at 1176 (majority opinion) (analyzing "one of the main purposes for which" the grant is intended) (citing Dole, 483 U.S. at 208).

221. Dole, 483 U.S. at 208 (emphasis added).

222. City of Los Angeles, 929 F.3d at 1184 (Wardlaw, J., dissenting).

223. City of Philadelphia v. Sessions, 280 F. Supp. 3d 579, 642 (E.D. Penn. 2017).

224. Dole, 483 U.S. at 214-15 (O'Connor, J., dissenting).

225. Id. at 214-15. 
because it seeks to catch, jail, and deport unauthorized migrants, even when they are not causing crime and disorder problems. It is under-inclusive because unauthorized migrants are not necessarily the ones causing crime and disorder problems in this country, rather research shows no causal connection. ${ }^{226}$ Additionally, police chiefs in some of the largest jurisdictions actually say that sanctuary cities "keep crime down" instead of increasing it. ${ }^{227}$ By applying the arguments from City of Philadelphia and the Justice O'Connor's over- and under-inclusive analysis, it is clear that the conditions attached to COPS funding - cooperating with Trump's anti-immigration policies - are not related to the COPS purpose-preventing crime and disorder - because being an unauthorized individual is not a crime (but rather a civil infraction) and they do not by-and-large cause disorder problems. Therefore, the conditions would likely fail the heightened relatedness prong and are violative of the Constitution.

\section{Comparison Analysis}

The same is true if the goals are defined as they should be-to increase police and community cooperation. To start, cracking down on immigration does not increase cooperation or trustworthiness between police and their communities; rather, it decreases it. ${ }^{228}$ Police chiefs indicate enforcing immigration law is not their responsibility ${ }^{229}$ and are also indicating that cooperating with federal immigration laws "would actually make their cities a lot more dangerous." 230 Some officers and agencies believe that such cooperation with federal immigration law inhibits their communication with their communities, particularly "immigrants [who] are more reluctant to talk to police." "231 This may create a "haven for criminals to prey upon immigrants who are afraid to report crimes to police." ${ }^{232}$ One county officer said that "gaining the trust of the immigrants who live in their communities has taken years of outreach" and that the efforts by the federal government to paint

226. Anna Flagg, Is There a Connection Between Undocumented Immigrants and Crime?, N.Y. TIMES (May 13, 2019), https://www.nytimes.com/2019/05/13/upshot/illegal-immigration-crimerates-research.html [https://perma.cc/RJW6-9VCL].

227. Chuck Wexler, Op-Ed: Police Chiefs Across the Country Support Sanctuary Cities because They Keep Crime Down, L.A. TIMES (Mar. 6, 2017, 4:00 AM), https://www.latimes.com/opinion/oped/la-oe-wexler-sanctuary-cities-immigration-crime-20170306-story.html [https://perma.cc/FUY3EWXE].

228. Alexia Fernández Campbell, US Police Chiefs Are Fighting the Crackdown on "Sanctuary Cities”, Vox (Aug. 18, 2017, 1:40 PM), https://www.vox.com/policy-andpolitics/2017/8/18/16130954/police-sanctuary-cities.

229. Id.

230. Id.

231. Id.

232. Id. 
officers as immigration officials diminishes the progress that has been made. ${ }^{233}$ Police chiefs across America have stated that "such efforts will have the unintended consequence of actually increasing crime and making their communities less safe" which nullifies the goals of community cooperation and safety behind the COPS grant program. ${ }^{234}$ Further, as stated, the goal behind the program is to foster positive relationships between police and their communities, not between police and the federal government. The condition creates relationships that go in the wrong direction. As the dissent in City of Los Angeles stated in its analysis on another issue, the "federal immigration preferences flout the clear congressional purpose of COPS grants-to promote partnership between local law enforcement and the communities they serve-by instead favoring partnerships between local police and federal immigration authorities." 235 Thus, there is seemingly no path by which the condition can reasonably serve the goals of the program.

\section{Another Possible Test}

Because the Court failed to clearly define the test of the relatedness prong, looking to other law may be helpful to define the test. Importantly, takings jurisprudence contains a similar relatedness test in its rough proportionality requirement. This test is another ends-means style constraint, making it potentially useful in defining the relatedness test. There are two primary cases that make up and define the rough proportionality test-Nollan v. California Coastal Commission ${ }^{236}$ and Dolan v. City of Tigard. ${ }^{237}$ In Nollan, landowners sued the federal government under the Fifth Amendment's takings clause ${ }^{238}$ for inserting a condition requiring the grant of a public easement on part of their beachfront property. ${ }^{239}$ The Supreme Court opined that the action of permanently occupying land through an easement would be a taking unless it substantially furthered legitimate state interests. ${ }^{240}$ The Court narrowly defined the purpose of the program-allowing public access from points

\footnotetext{
233. Id.

234. Wexler, supra note 227.

235. City of Los Angeles v. Barr, 929 F.3d 1163, 1192 (9th Cir. 2019) (Wardlaw, J., dissenting).

236. 483 U.S. 825 (1987).

237. 512 U.S. 374 (1994).

238. U.S. CONST. amend. V; Bill Funk, CPR Perspective: The Takings Clause of the Fifth Amendment, CTR. FOR PROGRESSIVE REFORM, http://www.progressivereform.org/perspTakings.cfm [https://perma.cc/H2VV-G4GY] (last visited Oct. 4, 2020) ("The Fifth Amendment ... includes a provision known as the Takings Clause, which states that 'private property [shall not] be taken for public use, without just compensation.' While the Fifth Amendment by itself only applies to actions by the federal government, the Fourteenth Amendment extends the Takings Clause to actions by state and local government as well.").

239. Nollan, 483 U.S. at 827.

240. Id. at 837 .
} 
inland to public beaches. ${ }^{241}$ The Court found that conditioning the grant of a permit on public access across the owner's land from one public beach to another was not within those purposes. ${ }^{242}$

Nollan, however, failed to define the degree of connection required between the conditions imposed and the impact of the proposed government action. ${ }^{243}$ The Court answered this question in Dolan. ${ }^{244}$ In Dolan, there was a permit stating the landowner had to convey part of her property to the government to be used for a storm drainage system and pedestrian pathway. ${ }^{245}$ The Supreme Court found this permit condition was an impermissible taking, and articulated that there must be a "rough proportionality" between the burden on the public created by the condition and the benefit to the public by the conveyance of land. ${ }^{246}$ For regulatory takings of property, the Court established a two-prong test. The first part requires finding an "essential nexus exists between the legitimate state interest and the permit condition exacted by the city."247 And second, the Court must decide the "required degree of connection." ${ }^{248}$ The second prong requires an "individualized determination" regarding both the connection between the impact and the conditions as well as a showing of "rough proportionality" between the benefit and the cost. ${ }^{249}$ In parsing out the rough proportionality test, many state courts employ a reasonable relationship test, but the Supreme Court opted for the "rough proportionality" nomenclature, because they were concerned about confusion between the phrase "reasonable relationship" and "rational basis." 250 This implies rough proportionality requires more than "rational basis review." 251

In Dolan, while the City passed the first prong of the "rough proportionality" test as the condition satisfied the goals of minimizing flooding, it failed the second prong of the test and was thus invalidated. ${ }^{252}$ This was because Ms. Dolan was unreasonably forced to give away her right to exclude individuals on her property and the City did not show specific

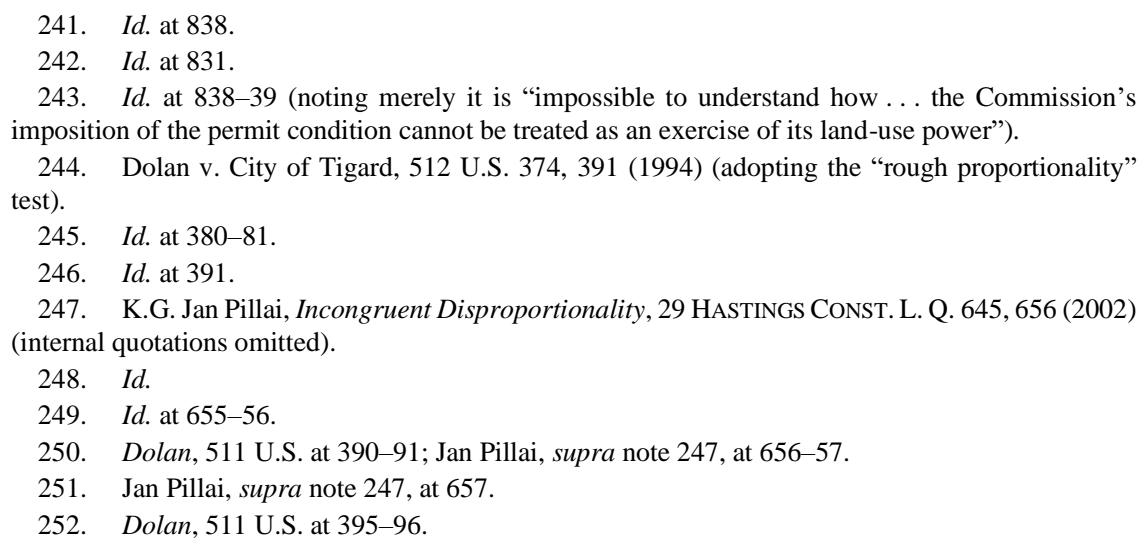


findings to justify the paths on Dolan's property it wanted to create. ${ }^{253}$ The test may not be "precisely defined," however, its "boundaries are roughly marked out." 254 Because of this, the rough proportionality test may be a good fit for defining the relatedness test more stringently, especially because it requires more than simply showing a rational basis.

If applied to the conditions in the instant case, it is unlikely that the immigration cooperation conditions would pass the rough proportionality test. On the first prong of the rough proportionality test, it is likely the federal government contains a valid interest in immigration enforcement because controlling immigration is a plenary power fairly unqualified in scope. ${ }^{255}$ However, the trouble with the first prong is the nexus requirement - whether there truly is a connection between immigration enforcement and the goals of the COPS grant program. Many arguments above show that these two things are unrelated. While this may be a potential hurdle, assuming without deciding that the nexus requirement would be met, the more rigorous analysis comes under the rough proportionality prong. While there is no mathematical formula for this prong, numbers can help guide the analysis. It is difficult to understand the numbers completely, as the program for this analysis is a grant condition. Thus, analyzing the amount of money Los Angeles would receive from the grant, versus the amount of money the community would have to spend on pursuing the Trump administration's immigration goals is helpful, although not necessarily dispositive.

For starters, one way to pursue immigration goals is through the $\S 287(\mathrm{~g})$ agreements, as stated in the guidelines for the COPS grant. ${ }^{256}$ Because there has been a fair amount of research into these agreements and their costs, they provide a unique insight into this analysis. Helping enforce federal immigration goals through these agreements can be a very costly venture. ${ }^{257}$ For example, in 2010 , one jurisdiction paid " $\$ 6.4$ million annually and \$25.9 million over five years to implement its $287(\mathrm{~g})$ agreement with ICE." 258 In other jurisdictions, the cooperation with ICE "cost taxpayers a whopping $\$ 7.9$ million and \$3.2 million per year, respectively." 259 Yet, these numbers do not even begin to capture the whole costs of the program. To further illustrate the

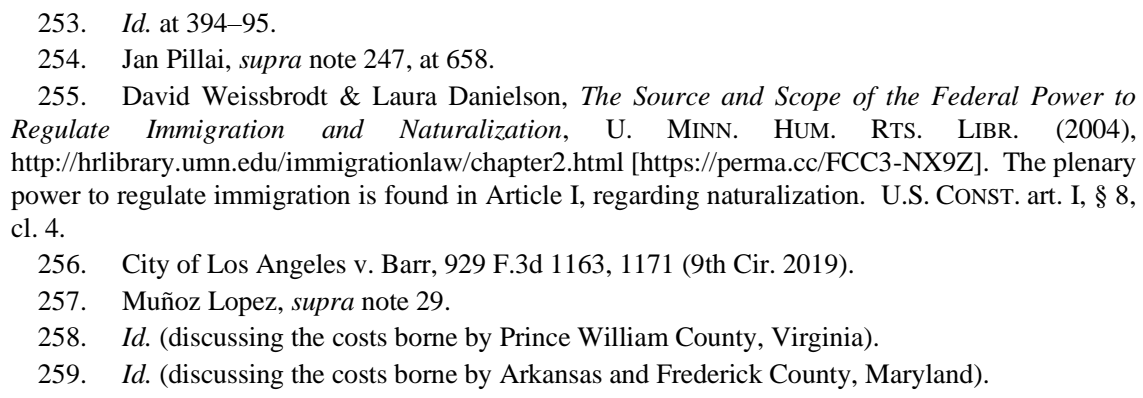


cost, Maricopa County, Arizona had a "\$1.3 million budget deficit"260 due to the payments for overtime work, and experienced " $\$ 43$ million in litigation fees that the county was ordered to pay due to lawsuits directly related to the program." ${ }^{261}$ Another tangential cost is the risk of migrant communities leaving the area due to arrest, deportation, or relocation. ${ }^{262}$ One study found, after reviewing 40 jurisdictions with these agreements, that immigrants provided " $\$ 66$ billion in spending power and contribute \$24 billion in tax revenue annually."263 In all, pursuing immigration goals for jurisdictions is very costly, which begs the question of whether the benefit of the COPS program is roughly proportional.

In the time that the government denied the Los Angeles application "the COPS Office awarded $\$ 98,503,539$ to 179 jurisdictions for the fiscal year 2017 application cycle. $" 264$ Based on this number, the average amount a jurisdiction received during this application cycle was around $\$ 550,300 .{ }^{265}$ Looking, for example at Prince William County, Virginia, the annual amount it spent to cooperate on immigration enforcement with the federal government was $\$ 6.4$ million, ${ }^{266}$ almost twelve times the average amount gained from the grant in 2017. While this is simply one example, it illustrates the fact that this allocation is not roughly proportional to the amount expended to pursue immigration goals. It is difficult to find numbers projecting dollar amounts a locality gains by possible decreases in crime, which also depends on whether the cooperation is effective, but even a generous number would not make the costs roughly proportional to the benefits. Thus, even if the program was able to overcome the first prong of the roughly proportional test, if based on numbers such as the aforementioned example, it certainly fails the second prong, and would be violative of the Spending Clause if this were the test for relatedness. By any strengthened relatedness test, the condition is still unconstitutional.

\section{CONCLUSION}

Despite the overwhelming evidence showing that the conditions would not pass a stricter relatedness test, a salient fact remains at the end of this analysis - relatedness has never before faced anything more than a cursory

\footnotetext{
260. Id.

261. Id.

262. Id.

263. Id.

264. City of Los Angeles v. Barr, 929 F.3d 1163, 1191 (9th Cir. 2019) (Wardlaw, J., dissenting).

265. $\$ 98,503,539 \div 179=\$ 550,299.10$.

266. See supra, note 258 and accompanying text.
} 
analysis. ${ }^{267}$ This fact alone should not be dispositive in discrediting the preceding analysis. Importantly, the Court has not defined "the outer bounds of the 'germaneness' or 'relatedness' limitation on the imposition of conditions under the spending power." 268 Accordingly, the Court in Dole did "not address whether conditions less directly related to the particular purpose of the expenditure might be outside the bounds of the spending power." ${ }^{269}$ Because the Supreme Court has explicitly failed to clearly define the relatedness test, it leaves the test open for the lower courts to define, or reinforce, as judges see fit. Strengthening relatedness does not fly in the face of judicial precedent, because the Supreme Court has not defined the test in depth, but rather should be encouraged in future jurisprudence.

267. See City of Los Angeles, 929 F.3d at 1175 (noting the Supreme Court has not invalidated a condition based on unrelatedness); see also NOLAN ET AL., supra note 13, at 318.

268. South Dakota v. Dole, 483 U.S. 203, 208 n.3 (1987).

269. Id. 